\title{
УКРАЇНСЬКА ІСТОРИЧНА АНТРОПОНІМІКА НА МЕЖІ СТОЛІТЬ
}

\section{Шийка С. В.}

\section{ВСТУП}

Інформатизація суспільного життя та розвиток сучасних наукових досліджень формують появу нових видових наукових галузей i синергетичних об'єднань. Так само, як з ономастики в середині минулого століття виділилася в окрему наукову галузь антропоніміка, можна вести мову про виокремлення історичної антропоніміки як самостійної дисципліни в структурі антропоніміки. Досліджуючи лексичний компонент, зокрема особові імена, імена по батькові, прізвища, прізвиська, псевдоніми та ін., історична антропонімія до свого понятійного змісту включає «етнографічну, історичну, соціальну, культурологічну інформацію і дуже швидко реагує на будь-які зміни, які відбуваються в суспільстві» ${ }^{1}$, тобто виступає синергетичною науковою сферою.

Формування термінологічного апарату, визначення об'єктів і предметів вивчення, постановка мети та завдань досліджень, розробка галузевої методології, співвідносність з антропонімікою й ономастикою як родовими науковими сферами - це неповний перелік питань, розв'язання яких сприятиме інституціоналізації історичної антропоніміки як наукової системи.

Предметом розгляду окремих питань історичної антропоніміки займалися українські вчені І. Желєзняк, Ю. Карпенко, С. Пахомова, Ю. Редько, М. Худаш, В. Шульгач та ін. Питання регіональної антропонімії в історичному розвитку висвітлені у працях Г. Бучка, Л. Кракалії, Л. Лісової, О. Неділько, С. Панцьо, Я. Пури, П. Чучки, Н. Шульської, Л. Ящук та ін. Динамічно розвиваються окремі напрями історичної антропоніміки з початком XXI ст.

Метою монографічної розвідки $\epsilon$ вивчення стану української історичної антропоніміки на межі XX i XXI ст. на основі реферативного аналізу фундаментальних праць із теорії власних особових назв, деяких прикладів корпусу регіональних досліджень та вироблення на цій основі орієнтовних напрямів розвитку історичної антропоніміки як наукової системи.

\footnotetext{
${ }^{1}$ Городилова Л.М. Историческая антропонимика XX-XXI вв.: направления и проблемы исследования. Вестник Бурятского государственного университета. 2012. Спец. вып. [1] А. С. 80.
} 


\section{1. Формування теоретичних засад української історичної антропоніміки}

Теоретичні основи української історичної антропоніміки започатковані у фундаментальній праці М. Худаша «З історії української антропонімії», яка вийшла друком у $1977 \mathrm{p}^{2}$. У ній автор виокремлює антропоніміку як окрему наукову галузь, яка почала системно розвиватися із середини XX ст. Об'єктом іiі вивчення є іменування людей або антропоніми, тому в процесі наукового опису використовується синтаксична конструкція «українська антропонімія» $\rightarrow$ «дослідження української антропонімії». Зважаючи на обмеженість теоретичного матеріалу, нерівномірність хронологічного й територіального вивчення різних типів антропонімів, дослідник диференціює українську антропонімію на сучасну й історичну. Суворого наукового визначення поняття «українська історична антропонімія» в монографії не наведено, що не заважає автору охарактеризувати їі особливості, стан і перспективи розвитку.

На час написання наукової праці українська історична антропоніміка обмежувалася вивченням антропонімійного фактажу писемних пам'яток на синхронному рівні, часто звужуючи предмет дослідження до якогось одного питання, переважно словотвору. Розглядалися дрібні й фрагментарні питання, переважали тематично розрізнені невеликі статті. Об'єднання їх разом із методологією опрацювання фактичного матеріалу і набутим досвідом в «єдину еволюційні цілісність» М. Худаш зараховує до першочергових завдань української антропонімії, яке стане базою для написання «великих синтезуючих монографій» та створення «спеціального курсу української антропоніміки». Актуалізується питання про формування структурованої системи науково-теоретичних, практико-методичних та джерелознавчих основ української історичної антропонімії як наукової галузі.

На основі узагальнень слов'янських ономастів, зокрема Т. Мілевського, О. Суперанської, В. Бланара, В. Никонова, дослідник підходить до визначення терміна «антропонімійна система», трактуючи його як «внутрішньо організовану сукупність засобів і моделей мовної ідентифікації особи, властивих тому чи іншому народові» ${ }^{3}$. Аналізуючи відомі в слов'янській ономастиці наукові інтерпретації антропонімійних систем у загальнотеоретичній проекції, він зараховує сучасну українську антропонімійну систему до «трийменних 3 обов'язковими трьома компонентами - власне ім'я + назва по батькові + прізвище» ${ }^{4}$. Способи ідентифікації особи в досліджуваний період дослідник класифікує на

${ }^{2}$ Худаш М.Л. 3 історії української антропонімії : монографія. Київ : «Наукова думка», 1977. 236 с.

${ }^{3}$ Там само. С. 76.

${ }^{4}$ Там само. С. 81 . 
три категорії: власне антропонімійні іменування, апелятивні іменування, мішані, або антропонімійно-апелятивні іменування 5 .

До основних понять антропонімічної галузі М. Худаш зараховує власні імена, назви по батькові, прізвища, прізвиська. Учений характеризує їх як «невід'ємну велику складову частину лексичного складу мови кожного народу», «антропонімійне багатство кожного народу», «продукт його історії». Успішність вивчення сучасного стану антропонімії залежить від докладного знання еволюційних процесів розвитку іменувань людей у процесі історичного поступу суспільства.

3-поміж актуальних проблем української історичної антропонімії виділяються питання про критерії поділу власних i загальних назв, межу між власними і загальними назвами, зокрема перехід загальної назви у власну. Дискусійними названі наявні наукові пояснення шляхів формування, стабілізації й остаточного сформування українських прізвищ. У дослідженні проаналізовано науково-дослідне значення антропонімії, джерела української історичної антропонімії, специфіку предмета і методи дослідження.

У тексті монографії простежуються три основні періоди розвитку української антропонімії: період початкового формування окремої антропонімійної системи (до XIV ст.), період стабілізації, або староукраїнський період (XIV - кінець XVIII ст.), період становлення сучасної трийменної української антропонімійної системи і початки наукового дослідження української антропонімії.

Загальнотеоретичні, екстралінгвістичні та джерелознавчі засади української антропоніміки проєктуються на площину практичного аналізу української антропонімії XIV - XVIII ст. - періоду стабілізації формування сучасної української антропонімійної системи.

Методологічний підхід щодо залучення ономастичних даних до лінгвістичної когнітології, яке простежується в етимологічних працях вчених другої половини $\mathrm{XX}$ ст., як зазначає В. Горпинич, матеріалізується і стає реальністю на початку нинішнього завдяки дисертаційному дослідженню О. Карпенко, репрезентованому в монографії «Проблематика когнітивної ономастики» (2006). Стратегія одеської дослідниці грунтується на когнітивних засадах про те, що «мова існує не в мовленні, а в людській свідомості, у ментальному лексиконі, у мозку, у вигляді концептів, що концепт і слово не $\epsilon$ тотожними явищами» ${ }^{6}$.

${ }^{5}$ Худаш М.Л. 3 історії української антропонімії : монографія. Київ : «Наукова думка», 1977. С. 110.

6 Горпинич В., Карпенко О.Ю. Проблематика когнітивної ономастики. Мовознавство. 2007. № 1. С. 83. 
Ключовими поняттями когнітивної ономастики виступають конщепт - «ніби згусток культури в свідомості людини», «зміст (сенс) слова»; символ - «знак», «умовне позначення якогось предмета, поняття або явища», «вираження сутності предмета», значення слова «спільне, притаманне різним носіям мови наповнення номінації»; зміст слова - «індивідуальне, суб'єктивне осмислення семантики слова мовцем», фрейм-від англ. frame «каркас, кістяк» ${ }^{7}$.

Індивідуальний антропонімічний фрейм, як зауважує О. Карпенко, групується за принципом егоцентризму довкола Я індивідуума i складається $з$ чотирьох кіл: 1) ти-коло, 2) Ви-коло (в обох особисте знання денотата $\epsilon$ обов'язковим), 3 ) ім'я-коло (C. $Ш$.), в якому вирішальну роль відіграє ім'я, а особисте знайомство $з$ денотатом не $\epsilon$ обов'язковим, 4) коло потенційних членів ментального лексикону. Структура мовного антропонімічного і взагалі онімічного фрейму спирається на сукупність усіх Я носіїв цієї мови. Еволюція від індивідуального до мовного онімічного фрейму реалізується шляхом складання та взаємокоригування індивідуальних фреймів ${ }^{8}$.

Об’єктом наукового дослідження С. Пахомової «Еволюція антропонімних формул у слов'янських мовах» (друге вид. 2012 р.) став морфологічний, словотвірний, лексикологічний, етимологічний i синтаксичний аналіз багатолексемних власних назв особи та антропонімних формул слов'янських мов на різних рівнях суспільного розвитку, які, за переконанням авторки, «все ще залишаються «білою плямою» на ономастичній карті слов'ян» ${ }^{9}$.

Структурно всі антропоніми дослідниця поділяє на однолексемні та багатолексемні. Багатолексемне власне іменування особи (антропонімне сполучення, складне іменування) тлумачиться як словосполучення (просте, складне), яке «складається з двох або більше повнозначних слів на основі підрядного зв'язку» ${ }^{10}$. Однак використання цього терміна доречне в певний період розвитку антропонімійної системи, 3 обов'язковим урахуванням хронології та лінгвістичного контексту. Тому С. Пахомова акцентує на понятті «антропонімна формула», за допомогою якого «передається неодновимірний, багатоступеневий характер номінації особи» i який, крім того, «виражає певну структурну закономірність» ${ }^{11}$. 3 окремими

\footnotetext{
${ }^{7}$ Карпенко О.Ю. Проблематика когнітивної ономастики : монографія. Одеса : Астропринт, 2006. 344 с.

${ }^{8}$ Там само. С. 122.

9 Пахомова С.М. Еволюція антропонімних формул у слов'янських мовах : монографія. Ужгород : Вид-во Олександри Гаркуші, 2012. С. 12.

10 Там само. С. 72.

${ }^{11}$ Там само. С. 74-75.
} 
застереженнями (про офіційність неофіційність іменування, розширення терміна «формула» на однолексемні антропоніми) вона погоджується 3 визначенням $H$. Подольської, що антропонімна формула - це «певний порядок розташування різних видів антропонімів та апелятивів в офіційному іменуванні людини цієї національності, стану, віросповідання в певну епоху» ${ }^{12}$.

3 урахуванням покомпонентного принципу в роботі класифіковано багатолексемні антропонімні формули у дві групи: «прості, які складаються з двох антрополексем (особове ім'я + патронім (ім'я по батькові, особове ім'я, прізвисько, відтопонімне означення, допрізвищеве родинне означення, прізвище), і складні, котрі утворені поєднанням трьох або більше антрополексем» ${ }^{13}$.

Наукова цінність дослідження полягає в розробці антропонімічної (власне історичної антропоніміки) термінології, синтезуючому підході до еволюції системи слов'янських антропонімних формул 3 урахуванням особливостей впливу особистісних, родинних та суспільних екстралінгвальних факторів. Матеріали та висновки дослідження можуть знайти застосування в ономастичній лексикографії, лінгвістичній славістиці, порівняльно-історичній граматиці, ономасіології та ін.

Антропонімна формульна методика реалізована в процесі лінгвістичного аналізу розвитку антропонімних формул у східнослов'янських, південнослов'янських i західнослов'янських мовах. У процесі дослідження, зокрема, розвитку антропонімних формул в українській мові на слов'янському тлі зроблено висновок, що співіснування в сучасному офіційно-діловому стилі трилексемної та дволексемної форми іменування має глибокі історичні витоки і $€$ результатом, відповідно, російського і польського чи - ширше західного впливу. Під час вибору однієї з них мають враховуватися протосхіднослов'янські корені і безперервна традиція уживання.

Монографічний блок із шести книг В. Шульгача «Дослідження 3 праслов'янської антропонімії» (2008, 2015, 2016, 2017, 2018, 2019) присвячений реконструкції великого масиву власних особових назв, які становлять праслов'янський антропонімний фонд. Автор розглядає префіксальні та суфіксальні словотвірні моделі на рівні відновлених чи слабо засвідчених апелятивів, які в результаті пропріалізації перейшли до класу онімів. В антропонімних етюдах подаються зразки генетичних мікросистем праслов'янських архетипів, об'єднаних у лексико-

12 Пахомова С.М. Еволюція антропонімних формул у слов'янських мовах : монографія. Ужгород : Вид-во Олександри Гаркуші, 2012. С. 73.

${ }^{13}$ Там само. С. $82,286$. 
словотвірні гнізда. Тим самим дослідник розвиває теоретичні й методологічні засади гніздового словотвірного підходу до етимологізації слов'янської лексики, правомірність якого обгрунтувала Р. Козлова ${ }^{14}$.

Відновлений корпус праслов'янських антропонімних архетипів В. Шульгач розцінює як «важливий фрагмент праслов'янського лексичного фонду» ${ }^{15}$, а методика розгляду структури праслов'янського слова на основі реконструйованого генетичного гнізда дає змогу, зокрема, встановити дериваційні зв'язки і відношення між його структурними компонентами, первинні i вторинні словотвірні морфеми, по-новому витлумачити низку питань порівняльноісторичної фонетики. Реконструйовані праслов'янські особові імена, утворені шляхом основоскладання і збережені переважно у складі історичних топонімів, доповнюють статті етимологічних словників, наприклад: *Borislavъ: мікротопонім Бориславово, особові імена: новгород. Бориславъ, XIII ст, болг. Борислав, XV, слвн. Borislav, н.-луж. Bóristaw, слов'ян. Borislau(us); *Miroslavъ: ойконім Мирославль, особові імена: слвн., хорв. Miroslav, прибалт. слов'ян. Miroslaw ${ }^{16}$.

Термінологічну базу української історичної антропоніміки В. Шульгач доповнює двома важливими тлумаченнями основних понять: «антропоніміка» і «праантропонім». На відміну від гідронімів чи ойконімів, антропонімію він вважає «рухомою в часі та просторі систему мовних одиниць». Під пропатронімом розуміє «потенційно живе слово, лінгвістичний прообраз сучасних чи вилучених 3 історичних та ін. джерел його репрезентантів, які пройшли тривалий шлях еволюції й подекуди зазнали значних формальних модифікацій» ${ }^{17}$.

Низку проблемних питань етимології, семантики основ та словотвору сербохорватських, українських та праслов'янських імен піднято у збірнику наукових праць I. Желєзняк «Слов’янська антропоніміка» (2011).

Зокрема, авторка порушує важливе питання історичної антропонімії про розуміння процесу «нарощення словотвірних типів у руслі загального збагачення лексики», про «причини, шляхи й форми появи та розвитку нових словотвірних моделей і типів». Характерною для пропріальної лексики дослідниця вважає номінацію шляхом онімізації

14 Козлова Р.М. Структура праславянского слова (Праславянское слово в генетическом гнезде) : монография. Гомель, 1997. 412 с.

15 Шульгач В.П. Нариси 3 праслов'янської антропонімії. Київ : Довіра, 2008. Ч. I. C. 229.

${ }^{16}$ Там само. С. 315,318 .

${ }^{17}$ Там само. С. 6. 
апелятива і називає три основні шляхи цього процесу: безпосередня онімізація апелятива, «конструювання словосполучення з наявних у мові окремих слів», «створення нової словесної одиниці як нового звукоморфемного комплексу». В етимологічних дослідженнях вона не віддає перевагу жодному 3 трьох методологічних компонентів фонетиці, словотвору чи семантиці. «Тільки конкретна лексика, зазначає дослідниця, що вивчається в цьому конкретному випадку, може спричинювати активізацію певної методики» ${ }^{18}$.

Окрім традиційних лінгвістичних питань, які характерні для антропонімічних досліджень, І. Желєзняк у статті «Світоглядний код слов'янської антропонімної лексики» визначає одне з головних завдань сучасної науки, яке також $є$ завданням історичної антропоніміки, «виявити своєрідність антропонімії як мовного джерела інформації про духовну культуру народу» ${ }^{19}$. Система особових імен у ній належить не тільки до категоріальної сфери природної мови, але й до особливого іiі міфологічного шару, утворюючи самостійний ономастичний код. Антропоніми розглядаються як елементи мови, які мають безпосередній зв'язок із духовною культурою народу i глибинні історичні витоки. Перші власні особові назви, на думку авторки, були витвором синтезу мови і світосприйняття людини ще до появи філософських теорій. Сутність конкретного слова-антропоніма спочатку була зрозуміла невеликому загалу. У результаті повторення ідентичних першоімен утворюються імена-знаки, які концентрують у собі смисл-зв'язок із навколишнім середовищем. Для відновлення мовного складу усього антропонімікону важливо відновити зв'язок конкретного особового імені з уявленням людини про навколишній світ i його зв'язок із конкретною людиною. «Слов'янський антропонімікон, - зауважує І. Желєзняк, - як нащадок індоєвропейського в лексичному контексті відбитий у руслі загального лексичного розвитку, а в семантичному - як віддзеркалення світогляду людності протягом тривалого часу» ${ }^{20}$.

Неоціненним $є$ внесок I. Желєзняк у формування ономастичної науки взагалі й історичної антропоніміки зокрема як системної наукової галузі та структурної фрагментації антропонімних досліджень. Яскраво ця теза демонструється на вивченні історії виникнення та функціонування слов'янських особових імен Світлан i

18 Желєзняк І.М. Слов'янська антропоніміка (вибрані статті). Київ : Кий, 2011. C. $215-216$.

${ }^{19}$ Там само. С. 241.

${ }^{20}$ Там само. С. 241-242. 
Світлана ${ }^{21}$. У структурі проведеного вченою комплексного дослідження виділяються такі частини:

- 3'ясування етимологічного походження <*světlъ(jb) + cуф. -an- / -ana- та поширення основи *svět- у слов'янській антропонімії;

- з'ясування концептуального змісту апелятивної основи й антропонімів;

- розширення семантичної палітри лексичного гнізда, зокрема доповненням колірної семантичної ознаки імен когнітивною характеристикою «глибокого відчуття людиною свого власного зв'язку зі стихією світла як початку всього живого» ${ }^{22}$;

- порівняльний ареальний i лексико-семантичний аналіз антропонімів і вихідних загальних основ у слов'янських мовах в еволюційній проєкції;

- дослідження сприйняття суті імені Світлана в художній літературі.

Новий напрям у розвитку сучасної ономастики - теоретичну, точніше типологічну ономастику - започаткували одеські науковці Олексій Скляренко та Ольга Скляренко в п’ятикнижній збірці монографій «Типологічна ономастика». Перша книга цієї серії «Лексико-семантичні особливості онімного простору» вийшла друком у 2012 році. Порівняльне вивчення загального спектру ономастичної лексики за допомогою ономастичного мислення, ономастичних традицій і смаків, ономастичних ідей продуктивно може бути також застосоване конкретно до досліджень історичної антропоніміки.

«Типологічне зіставлення власних імен має важливе значення для створення загальної ономастичної теорії» ${ }^{23}$. Комплексний аналіз конкретного ономастикону складається 3 інтралінгвального та екстралінгвального компонентів: зіставно-типологічного, структурнословотвірного, лексико-семантичного, соціально-функціонального, психолого-когнітивного.

Особливе значення в цій праці надається поясненню основного ономастичного поняття - власному імені. Власні імена автори характеризують як «специфічне лінгвістичне ядро кожного етносу», «найдавніший лексичний шар мови», «не лише шар найдавніших утворень, але й наймолодший шар лексики», «згущене в смисловому

${ }^{21}$ Желєзняк I.М. Слов'янська антропоніміка (вибрані статті). Київ : Кий, 2011. C. $243-250$.

22 Там само. С. 249.

${ }^{23}$ Скляренко О., Скляренко О. Типологічна ономастика : монографія : у 5 кн. Книга перша : Лексико-семантичні особливості онімного простору. Одеса : Астропринт, 2012. С. 28. 
відношенні слово», «живий нерв реального досвіду» ${ }^{24}$. Наводяться означення й інших ономастичних понять i категорій, зокрема антропонімний титул, індивідуальне ономастичне поняття, клас ономастичних понять, онім, пропріальна лексика, протоонім. Терміном «ономастика» називається «розділ мовознавства, який вивчає пропріальну лексику, будь-які власні імена, закономірності виникнення, розвитку, зміни, функціонування, поширення і структури власних імен у мові та мовленні, в літературній і діалектній сферах» ${ }^{25}$. Пропріальна лексика розглядається як багатошарова, ієрархічна, 3 різним ступенем ономастичності, ономастична піраміда, в основі якої знаходяться загальні назви, здатні до онімізації ${ }^{26}$.

Порушуючи питання про методологію ономастичного пізнання в абстрактній та конкретній формі, автори дефініціюють останню як «сукупність вихідних принципів, якими керується лінгвіст на різних етапах дослідження» ${ }^{27}$. До методологічних принципів ономастики зараховано принципи амбівалентності, системності, соціальної зумовленості, функціональності, переходу кількісних змін в якісні, одиничності, множинності. Найголовнішою серед зазначених вчені вважають амбівалентність сутностей. Прояв іманентної амбівалентності ономастичної сфери, що виявляється в одночасному існуванні у вертикальній або діахронічній і горизонтальній або синхронічній площинах, може використовуватися стосовно досліджень історичної антропонімії.

Дієвість наукової теорії забезпечується поширенням серед зацікавленого загалу методики засвоєння окреслених знань і перевірка iii на практиці. 3 цього приводу варто зазначити важливу роль спеціальних курсів із вивчення ономастики й антропоніміки, зокрема у закладах вищої освіти. У 2014 р. виданий навчальний посібник «Українська ономастика: антропоніміка», автором якого $\epsilon$ Л. Кравченко. Перша його частина - це виклад теоретичного матеріалу, друга - плани практичних занять для студентів, питання для самостійної, індивідуальної та пошукової роботи ${ }^{28}$.

Виклад теоретичного матеріалу здійснено за таким родово-видовим принципом: антропоніміка розглядається як складова частина,

${ }^{24}$ Скляренко О., Скляренко О. Типологічна ономастика : монографія : у 5 кн. Книга перша : Лексико-семантичні особливості онімного простору. Одеса : Астропринт, 2012. С. 15, 17.

${ }^{25}$ Там само. С. 75.

${ }^{26}$ Там само. C. 56.

${ }^{27}$ Там само. С. 18.

${ }^{28}$ Кравченко Л.О. Українська ономастика : навч. посібник. Київ : Знання, 2014. 239 c. 
підмножина ономастики (подібно історична антропоніміка, як i теоретична, описова, прикладна, літературна, когнітивна - вид антропоніміки (С.Ш.). Визначено термінологічну тріаду наукової галузі: антропонім - особова назва, антропонімія - певна сукупність особових імен, антропоніміка - наукове дослідження $\mathrm{ix}^{29}$. Наведено означення основних та похідних антропонімічних понять, розглянуто різноманітні антропонімні класифікації. 3 урахуванням висновків наукових досліджень українських вчених детально проаналізовано особові імена людей та їхні розмовно-побутові варіанти, імена по батькові, прізвища, прізвиська та інші неофіційні іменування особи. Особливе місце відведене поясненню історії виникнення і розвитку українських прізвищ, розгляду їх лексичної бази, словотвірних особливостей та варіантності.

Авторка посібника акцентує на необхідності виокремлення 3 онімного простору й повноцінного вивчення антропонімної лексики на всіх рівнях мови - лексико-семантичному, морфологічному, словотвірному, фонетичному, синтаксичному. Зазначається також, що уточненням питань, пов'язаних із семантикою власних назв, треба «пояснити специфіку інформації, значення та функції пропріативів, а також їхні системні зв'язки» ${ }^{30}$.

В історії розвитку особових імен українців виокремлено три основні етапи: дохристиянський (до 988 р.), християнський (XI - початок XX ст.), сучасний (XX - XXI ст.). Два останніх поділяються на підетапи 3 описом характерних для розвитку імен людей процесів ${ }^{31}$. Така методика хронологічного розподілу, на нашу думку, може бути застосована як основиа класифікації об'єктів і знань про них в історичній антропоніміці.

\section{2. Дослідження регіональних антропоніміконів}

Актуалізовані наприкінці минулого століття регіональні антропонімічні дослідження, анотовані в оглядах Л. Лісової, М. Торчинського, О. Юцишиної та ін., активно продовжуються й на початку нового. Зосередимо увагу на трьох останніх дисертаційних працях, присвячених розгляду різних видів регіональних антропонімів, які функціонували впродовж деякого історичного періоду.

Метою кандидатської дисертації Т. Буги «Динаміка особових імен Центральної Донеччини (кінець XIX - початок XXI ст.)» (2010) $є$

C. 17.

${ }^{29}$ Кравченко Л.О. Українська ономастика : навч. посібник. Київ : Знання, 2014.

\footnotetext{
${ }^{30}$ Там само. С. 9.

${ }^{31}$ Там само. С. 23.
} 
виявлення та аналіз чоловічих $\mathrm{i}$ жіночих імен в українських $\mathrm{i}$ українсько-змішаних родинах сіл Центральної Донеччини з кінця XIX до початку XXI ст. У дослідженні проаналізовано 317 чоловічих і 351 жіноче ім'я. За походженням виділено чотири основні групи особових назв: канонічні, автохтонні слов'янські, запозичені й новотвори. Упродовж досліджуваного періоду, як підсумовує авторка, «відбувається заміна офіційних форм канонічних імен на нові, більш пристосовані до української мови, формується група застарілих імен, що вийшли 3 ужитку після введення громадянської реєстрації новонароджених, статусу офіційних онімів набувають деякі гіпокористики» ${ }^{32}$.

Удосконаленню методологічної основи антропонімічних досліджень сприятиме підрозділ «Основи статистичного аналізу іменника», в якому розкрито сутність статистичного методу дослідження й доцільність його застосування для аналізу динаміки особових імен. Зазначено, що статистичний метод дає змогу зробити цілісний аналіз іменника, зокрема, схарактеризувати склад іменника і простежити його оновлення, здійснити кількісні і хронологічні порівняння, визначити постійні та частотні статистичні групи імен тощо.

Дослідження лексико-семантичних та структурно-словотвірних особливостей прізвищ жителів м. Нововолинська Волинської області загальною кількістю понад 5 тисяч одиниць здійснено О. Хвіщуком у кандидатській роботі «Структурно-семантичний аналіз прізвищ жителів м. Нововолинська Волинської області» $(2017)^{33}$.

Виклад матеріалу дослідження проведено за дедуктивною методикою. У першому розділі кваліфікаційної роботи розглянуто прізвища з позицій лінгвального феномена і соціокультурного явища та різні підходи до класифікації прізвищевого матеріалу. Основними ознаками прізвищ визначено незмінність, можливість успадкування та юридичну обов'язковість іменування. Розглядаються також терміни «прізвищеві назви», «прізвиська» та їх відмінності від «прізвища». У другому розділі проаналізовані регіональні прізвища, утворені лексико-семантичним способом та за допомогою суфіксів. Висновки автора конкретизують історію становлення та розвитку сучасного українського антропонімікону, зокрема на територіях нового заселення.

Офіційна трикомпонентна система іменування в Україні - ім'я + ім'я по батькові + прізвище - аналізується в теоретичному та

32 Буга Т.В. Динаміка особових імен Центральної Донеччини (кінець XIX початок XXI ст.) : автореф. дис. ... канд. філол. наук : 10.02.01. Донецьк, 2010. 22 с.

33 Хвіщук О.В. Структурно-семантичний аналіз прізвищ жителів м. Нововолинська Волинської області : дис. ... канд. філол. наук : 10.02.01. Луцьк, 2017. $275 \mathrm{c}$. 
практичному аспектах сучасними ономастами. Тим часом дослідження української неофіційної системи іменування недостатнє. Цю прогалину заповнює дослідження О. Вербовецької «Неофіційна антропонімія Тернопільщини» (2016).

Зупинимося на двох ціннісних аспектах цієї кваліфікаційної роботи. По-перше, надзвичайно важливою $є$ картотека неофіційних іменувань, яка налічує 2750 варіантів 280 особових імен жителів Тернопільщини та методика їх зібрання. По-друге, методика цілісного і всебічного аналізу антропонімів, яка включає функціональну систематизацію i класифікацію неофіційних регіональних іменувань, дослідження словотвірної структури та емоційного забарвлення розмовних варіантів імен, аналіз індивідуальних та групових прізвиськ за мотивами номінації, розкриття словотвірних та конотативних особливостей антропонімів, з'ясування мотивів виникнення індивідуальних іменувань за родичами i визначення способів їх творення, виокремлення сімейно-родових назв та встановлення особливостей їх функціонування ${ }^{34}$.

Наведені приклади все ж фрагментарно репрезентують дослідження певних видів антропонімів, географічні і часові ареали їх поширення. Найбільш повно, масштабно і всебічно з-поміж інших регіонів України вивчена сучасна й історична антропонімія Закарпаття завдяки великій науковій діяльності професора П. Чучки. Результати їі узагальнені й опубліковані в друкованих та електронних джерелах на початку XXI ст.

Одним із перших видань цієї серії $\epsilon$ історико-етимологічний словник «Прізвища закарпатських українців» (2005). Антропонімним фактажем для цієї лексикографічної праці послужили понад 11500 прізвищ корінних українців Закарпаття, які функціонують починаючи з середини минулого століття і дотепер. Спочатку автором розглядаються загальні питання теорії прізвища, історія становлення та специфіка функціонування родових регіональних назв. Лінгвістичний аналіз антропонімів включає визначення їx мовного i правового статусів, розгляд глобальних, національних і територіальних ознак, статистику варіантності прізвищ, дослідження лексичного значення, морфемної будови принципів етимологізування, правопису, вимови та відмінювання тощо ${ }^{35}$.

Чільне місце серед репрезентованих наукових праць посідає монографія «Антропонімія Закарпаття», видана у 2008 р. за рукописом

34 Вербовецька О.С. Неофіційна антропонімія Тернопільщини : дис. ... канд. філол. наук : 10.02.01. Тернопіль, 2016. 366 с.

35 Чучка П.П. Прізвища закарпатських українців. Історико-етимологічний словник. Львів : Світ, 2005. 704 с. 
докторської дисертації вченого, захищеної в 1969 р ${ }^{36}$.. Значне за обсягом дослідження базується на багатому i достовірному регіональному антропонімному матеріалі - 30000 найменувань, у тому числі 15000 розмовних варіантів прізвищ (українські прізвища становлять понад $80 \%$ від загальної кількості), більше 12 тис. прізвиськ і понад 2 тис. варіантів власних особових імен, який піддається глибокій і різноплановій інтерпретації. У вступі, як зазначає авторка рецензії С. Пахомова, наведені «матеріали про історію вивчення антропонімії Закарпаття, про офіційну і народну системи номінації особи, про місце антропонімів у словниковому складі мови та ін.», які надалі закладали підвалини української ономастики ${ }^{37}$. Особові імена П. Чучка аналізує в етимологічному i словотвірному аспектах, характеризує частотність використання й ареал поширення, визначає соціальне і сакральне в їх змісті. Детально розглядаються також офіційні індивідуальні прізвища, які проаналізовано залежно від етимології, способів творення, лексико-семантичних особливостей твірних основ та неофіційні - сімейні, родичівські прізвища або прізвиська. Матеріали монографії і методика дослідження можуть бути використані в процесі вивчення історичного й сучасного антропонімікону інших територій держави.

Важливою лексикографічною працею 3 історичної антропонімії $€$ історико-етимологічний словник «Слов'янські особові імена українців», який видано у $2011 \mathrm{p}^{38}$. . Під терміном «слов'янські особові імена українців» у ньому маються на увазі «не будь-які імена, носіями яких $\epsilon$ або були українці, а тільки ті власні імена слов'янської етимології, носіями яких $є$ або були особи української національної (етнічної) належності» ${ }^{39}$. У теоретичній частині проаналізовано часові й просторові межі їх функціонування, первісна семантика, морфемна структура i стилістичні особливості. В основній частині схарактеризовано 2000 слов'янських чоловічих і жіночих імен українців.

Зазначені антропонімічні видання разом із друкованими та інтернетваріантами інших наукових праць ученого, зокрема «Розвиток імен та прізвищ» монографії «Історія української мови. Лексика i

36 Чучка П.П. Антропонімія Закарпаття : монографія. Київ : ТОВ «Папірус», 2008. $672 \mathrm{c}$

37 Пахомова С. Монографія про антропонімію Закарпаття. Науковий вісник Ужгородського університету. Серія : Філологія. 2009. Вип. 21. С. 144.

38 Чучка П.П. Слов'янські особові імена українців : історико-етимологічний словник. Ужгород : Ліра, 2011. 432 с.

${ }^{39}$ Там само. С. 4. 
фразеологія» $^{40}$ та бібліографічним покажчиком «Покликання», випущеним до 90-річчя від дня народження Павла Павловича Чучки ${ }^{41}$, утворюють своєрідне «ономастичне портфоліо» класика ономастичної науки. Доповнивши його здобутками учнів і послідовників П. Чучки, а також результатами досліджень антропонімікону цього регіону іншими вченими, одержуємо повний «антропонімний кейс» ареалу українського Закарпаття.

Створення подібних «ономастичних портфоліо» та формування «антропонімних регіональних кейсів» покликане структурувати як ономастичну науку загалом, так і ії галузеві й ареальні відгалуження, серед яких і систему знань 3 історичної регіональної антропоніміки.

Проаналізуємо динаміку наповненості «антропонімного кейсу» історичної Ровенщини. В основі іiі лежать наукові та науково-популярні праці Я. Пури, результати ономастичних досліджень В. Шульгача та С. Шийки. Етапними віхами досліджень антропонімії краю $є$ такі публікації:

- словник «Сучасні прізвища Рівненщини» Я. Пури ${ }^{42}$;

- аналітичні статті Н. Мандрик «Сучасний стан та історія української антропоніміки (на матеріалі прізвищ Рівненщини) ${ }^{43}$ та «Українські прізвища 3 суфіксами (' ) ук, - чук на Рівненщині» ${ }^{44}$ за матеріалами Словника Я. Пури;

- наукові статті за результатами системних досліджень антропонімії історичної Ровенщини, проведених С. Шийкою.

Формування цілісної системи лінгвістичних знань про власні особові назви людей, які проживали на території старожитнього ровенського краю - краю 3 глибокою архаїкою $\mathrm{i}$ мовною диференційованістю, у фахових статтях С. Шийки розпочато 3 давньоруського періоду. Ресурсною базою для наукових досліджень послужили антропоніми початку другого тисячоліття, вилучені 3 літописних джерел, співвідносні з територією історичної Ровенщини. Звичайно, воно $\epsilon$ аналітично наближеним, 3 огляду на низку ексталінгвальних факторів, серед яких: умовність тодішньої території,

40 Чучка П.П. Розвиток імен та прізвищ. Історія української мови: Лексика $i$ фразеологія. Київ : Наукова думка, 1983. С. 592-620.

${ }^{41}$ Покликання : біобібліогр. покажч. : до 90-річчя від дня народження Павла Павловича Чучки / уклад. : Л.О. Мельник та ін. Ужгород : Вид-во Олександри Гаркуші, 2018. 224 с.

42 Пура Я.О. Сучасні прізвища Рівненщини. Рівне, 1990. 202 с.

43 Мандрик Н.В. Сучасний стан та історія української антропоніміки (на матеріалі прізвищ Рівненщини». Наукові записки. Серія «Філологічна». 2010. Вип. 13. С. 430-437.

${ }^{44}$ Мандрик Н.В. Українські прізвища з суфіксами (' ) ук, - чук на Рівненщині. Наукові записки. Серія «Філологічна». 2013. Вип. 40. С. 78-80. 
яка зарахована до сучасної адміністративної області; відносність зв'язку між носіями власних особових назв і місцевістю дослідження (народження, князювання, тимчасове перебування, посесивні залежності тощо); незначна кількість, переважно літописних текстів, домінування в них княжих імен.

Дослідження структурних особливостей особових назв у статті «Структурні особливості давньоруських особових назв історичної Ровенщини» (2019) здійснено за методикою покомпонентного аналізу 3 використанням різних структурно-класифікаційних схем, серед яких загальна: власні особові назви $\rightarrow$ структурно-класифікаційні групи іменувань особи (однослівні, двослівні, трислівні) $\rightarrow$ структурнокласифікаційні підгрупи й різновиди іменувань; для дволексемних антропонімних формул: особове ім'я $\rightarrow$ патронім, особове ім'я $\rightarrow$ прізвисько, особове ім'я $\rightarrow$ ад'єктивний топонім. Регіональні давньоруські імена класифіковано у три системні антропонійні підгрупи: прості одноосновні імена, до яких належать відапелятивні утворення та різноманітні запозичення; складні двоосновні імена слов'янського походження; похідні імена. Серед трилексемних іменувань виділено синтетичні моделі та аналітичні конструкції 3 термінами спорідненості: син, дочка, брат, сестра, внук ${ }^{45}$.

Мета i завдання дослідження «Особливості давньоруського жіночого іменника історичної Ровенщини» (2020) реалізовані за планом: 1) визначення позалінгвальних факторів, які ускладнюють реконструкцію особових назв; 2) з'ясування причини їх нечисленності; 3) дослідження походження і змісту зафіксованих іменувань; 4) розгляд жіночого імені як антропонімної формули. Розгляд слов'янських автохтонних жіночих імен, похідних від чоловічих двоосновних композитів, наприклад Всеслава < Всеслав + суф. -a, мотивує зарахування їх до «наслідкових» або «вторинних» антропонімних фреймів $^{46}$.

\section{ВИСНОВКИ}

За результатами реферативного аналізу фундаментальних праць із теорії власних особових назв, деяких прикладів корпусу регіональних досліджень можна зробити висновок про пожвавлення лінгвістичних студій з української історичної антропоніміки на межі XX і XXI ст.

${ }^{45}$ Шийка С.В. Структурні особливості давньоруських особових назв історичної Ровенщини. Вчені записки ТНУ імені В.І. Вернадського. Серія Філологія. Соціальні комунікації. 2019. Т. 30 (69). № 4. С. 42-47.

46 Шийка С.В. Особливості давньоруського жіночого іменника історичної Ровенщини. Теоретичні й прикладні проблеми сучасної філологї. Слов'янськ : Вид-во Б.І. Маторіна, 2020. Вип. 10. Частина I. С. 102-108. 
Активно проходить формування термінологічної системи. До основних понять антропонімічної галузі М. Худаш зараховує власні імена, назви по батькові, прізвища, прізвиська. Він також вводить поняття «антропонімійна система», «українська історична антропонімія». В. Шульгач означає терміни «антропоніміка» i «праантропонім». Олексій та Ольга Скляренки наводять означення ономастичних понять i категорій, зокрема антропонімний титул, індивідуальне ономастичне поняття, клас ономастичних понять, онім, пропріальна лексика, протоонім.

3-поміж актуальних проблем української історичної антропонімії виділяються питання взаємозв'язку і взаємозалежності власних і загальних назв, дослідження особових імен, пояснення шляхів формування, стабілізації і остаточного сформування українських прізвищ.

На основі відомих у Славії наукових інтерпретацій антропонімійних систем пояснюється українська трийменна система іменування 3 обов'язковими компонентами: - власне ім'я + назва по батькові + прізвище. С. Пахомова проаналізувала еволюцію антропонімних формул у слов'янських мовах.

Розвиваються нові напрями ономастики і відповідно антропоніміки. Серед них когнітивна або концептна ономастика (I. Желєзняк, О. Карпенко), реконструкція праслов'янського антропонімного фонду (В. Шульгач), системна і структурна фрагментація антропонімних досліджень (І. Желєзняк), типологічна або теоретична ономастика (Олексій та Ольга Скляренки).

Формується методологія антропонімного пізнання в абстрактній та конкретній формі, розробляються галузеві методи наукових досліджень. Найголовнішим методологічним принципом виступає принцип амбівалентності сутностей, що передбачає одночасне вивчення антропонімікону у вертикальній або діахронічній $\mathrm{i}$ горизонтальній чи синхронічній площинах.

Сучасні регіональні дослідження 3 історичної антропонімії набувають частотного характеру, проте не усі регіони досліджені однаково. Завдяки сподвижницькій діяльності П. Чучки повно вивчена антропонімія Закарпаття. Розпочато системне вивчення антропонімікону території історичної Рівненщини. Доцільним $\epsilon$ створення авторських «ономастичних портфоліо» та формування «антропонімних регіональних кейсів» як основи цілісності системи ономастичних та регіональних антропонімічних знань.

Перспективи подальших досліджень пов'язані $з$ удосконаленням теоретичних засад української історичної антропоніміки як наукової галузі, прикладним застосуванням їх до вивчення антропонімів регіонів України і вибудовуванням на цій основі цілісної системи лінгвістичних знань про особові іменування людей. 


\section{АНОТАЦІЯ}

Розвідку присвячено аналізу стану української історичної антропоніміки на межі XX і XXI ст. Шляхом реферування сучасних наукових праць проаналізовано теоретичні основи i прикладне застосування галузевих засад. Означено основні антропонімні поняття i категорії. Розглянуто формульний підхід до іменування людей. Серед актуальних проблем виділено питання взаємозв'язку i взаємозалежності власних і загальних назв, дослідження особових імен, пояснення шляхів формування, стабілізації і остаточного сформування українських прізвищ. Акцентовано увагу на нових напрямах ономастичних досліджень, серед яких: когнітивна або концептна ономастика, реконструкція праслов'янського антропонімного фонду, системна i структурна фрагментація антропонімних досліджень, типологічна або теоретична ономастика. Стверджується, що створення авторських «ономастичних портфоліо» та формування «антропонімних регіональних кейсів» сприятиме цілісності системи ономастичних та регіональних антропонімічних відомостей.

\section{ЛIТЕРАТУРА}

1. Буга Т.В. Динаміка особових імен Центральної Донеччини (XIX - XXI ст.) : автореф. дис. ... канд. філол. наук : 10.02.01. Донецьк, 2010. $22 \mathrm{c}$.

2. Вербовецька О.С. Неофіційна антропонімія Тернопільщини : дис. ... канд. філол. наук : 10.02.01. Тернопіль, 2016. 366 с.

3. Городилова Л.М. Историческая антропонимика XX-XXI вв.: направления и проблемы исследования. Вестник Бурятского государственного университета. 2012. Спец. вып. [1] А. С. 79-83.

4. Горпинич В. Рецензія : Карпенко О.Ю. Проблематика когнітивної ономастики. Мовознавство. 2007. № 1. С. 83-84.

5. Желєзняк I.M. Слов'янська антропоніміка (вибрані статті). Київ : Кий, 2011. 288 с.

6. Карпенко О.Ю. Проблематика когнітивної ономастики : монографія. Одеса : Астропринт, 2006. 344 с.

7. Козлова Р.М. Структура праславянского слова (Праславянское слово в генетическом гнезде) : монография. Гомель, 1997. 412 с.

8. Кравченко Л.О. Українська ономастика : навч. посібник. Київ : Знання, 2014. 239 с.

9. Мандрик Н.В. Сучасний стан та історія української антропоніміки (на матеріалі прізвищ Рівненщини». Наукові записки. Серія «Філологічна». 2010. Вип. 13. С. 430-437.

10. Мандрик Н.В. Українські прізвища з суфіксами (' ) ук, - чук на Рівненщині. Наукові записки. Серія «Філологічна». 2013. Вип. 40. C. $78-80$. 
11. Пахомова С. Монографія про антропонімію Закарпаття. Науковий вісник Ужгородського ун-ту. Серія : Філологія. 2009. Вип. 21. С. 144-145.

12. Пахомова С.М. Еволюція антропонімних формул у слов'янських мовах : монографія. Ужгород : Вид-во Олександри Гаркуші, 2012. 344 с.

13. Покликання : біобібліогр. покажч. до 90-річчя від дня народження П.П. Чучки / уклад. : Л.О. Мельник. Ужгород : Вид-во О. Гаркуші, 2018. 224 с.

14. Пура Я.О. Сучасні прізвища Рівненщини. Рівне, 1990. 202 с.

15. Скляренко О., Скляренко О. Типологічна ономастика : монографія : у 5 кн. Книга перша : Лексико-семантичні особливості онімного простору. Одеса : Астропринт, 2012. 416 с.

16. Хвіщук О.В. Структурно-семантичний аналіз прізвищ жителів м. Нововолинська Волинської області : дис. ... канд. філол. наук : 10.02.01. Луцьк, 2017. 275 с.

17. Худаш М.Л. 3 історії української антропонімії : монографія. Київ : «Наукова думка» 1977. $236 \mathrm{c.}$

18. Чучка П.П. Розвиток імен та прізвищ. Історія украӥнської мови: Лексика і фразеологія. Київ : Наукова думка, 1983. С. 592-620.

19. Чучка П.П. Антропонімія Закарпаття : монографія. Київ : ТОВ «Папірус», 2008. 672 с.

20. Чучка П.П. Прізвища закарпатських українців. Історикоетимологічний словник. Львів : Світ, 2005. 704 с.

21. Чучка П.П. Слов'янські особові імена українців : історикоетимологічний словник. Ужгород : Ліра, 2011. 432 с.

22. Шийка С.В. Структурні особливості давньоруських особових назв історичної Ровенщини. Вчені записки ТНУ імені В.I. Вернадського. Серія Філологія. Соціальні комунікації. 2019. Т. 30 (69). № 4. С. 42-47.

23. Шийка С.В. Особливості давньоруського жіночого іменника історичної Ровенщини. Теоретичні й прикладні проблеми сучасної філологіï. Слов'янськ : Вид-во Б.І. Маторіна, 2020. Вип. 10. Частина I. C. $102-108$.

24. Шульгач В.П. Нариси 3 праслов'янської антропонімії. Київ : Довіра, 2008. Ч. І. 413 с.

Information about the author: Shyyka S. V.,

Candidate of Philological Sciences, Assistant Professor at the Department Ukrainian Studies National University of Water Management and Natural Resources Use 11, Cathedral str., Rivne, 33000, Ukraine 